\title{
Classical and Molecular Approaches to Breeding Fruit and Nut Crops for Disease Resistance
}

\author{
Shawn A. Mehlenbacher \\ Department of Horticulture, Oregon State University, Agriculture and Life Sciences Building 4017, \\ Corvallis, OR 97331
}

Disease resistance is an objective of most plant breeding programs and fruit and nut crops are no exception. Classical methods have been used successfully to develop cultivars resistant to several major diseases, while the level of success with other pathogens has been less striking. Currently, there is considerable activity in developing linkage maps for these crops and in transformation. Marker-assisted selection (MAS) and transformation appear to be valuable additions to the tools available to develop new and better cultivars. This paper will review the current status of breeding fruit and nut crops for disease resistance. A few key diseases of the major fruit and nut crops and the methods used to identify resistant seedlings will be described. The current status of linkage mapping and transformation in these crops will be presented, and the application of these tools in developing diseaseresistant cultivars will be discussed.

Compared to the major field crops, comparatively little effort is devoted to fruit and nut crop improvement. Although several programs exist for strawberry (Fragaria $\times$ ananassa Duch.) and peach [Prunus persica (L.) Batsch.], the number of programs and full-time equivalents (FTE) devoted to the other fruit and nut crops is quite small. Yet, in spite of this, new cultivars of several crops, including strawberry, raspberry (Rubus spp.), blueberry (Vaccinium corymbosum L.), table grape (Vitis spp.), peach, and walnut (Juglans regia L.), have had considerable impact on their respective industries. Success with other crops has been less impressive. For many crops, breeding programs have been underway for a short time relative to the length of the breeding cycle. The long juvenile phase of tree crops limits the amount of genetic improvement per year, and the large plant size makes each increment of improvement expensive (Hansche, 1983). In addition, in wine grapes, apples (Malus $\times$ domestica Borkh.), and pears (Pyrus communis L.), industries have been built around a small number of selected cultivars with wide name recognition, and these industries are reluctant to change.

\section{A BREEDING PROGRAM FOR CLONALLY PROPAGATED CROPS}

In modern agriculture, fruit and nut cultivars are propagated asexually for commercial production, and the same breeding methods are used for all. Because the methods used for clonally propagated crops are quite different from those used to develop homozygous lines and $F_{1}$ hybrid varieties, much of the plant breeding and gene mapping literature is not applicable to fruit and nut crops. It is therefore appropriate to review the procedures used for clonally propagated crops.

Cultivars of fruit and nut crops are superior combinations of genes, and clonal propagation allows faithful reproduction of the superior genotype. In general, cultivars are highly heterozygous and inbreeding results in a decline in vigor and fertility, as is the case with naturally cross-pollinated crops. Deleterious recessive alleles are carried by the leading cultivars of many crops.

The first step in any breeding program is to define and prioritize the objectives. This step implies that genetic variation is present for each of the traits to be improved. If such variation is not known, germplasm must first be collected and evaluated. For each trait, a minimal acceptable standard should be established, and a reliable evaluation

Received for publication 20 Oct. 1994. Accepted for publication 17 Nov. 1994. Oregon Agricultural Experiment Station publication no. 10,594. The cost of publishing this paper was defrayed in part by the payment of page charges. Under postal regulations, this paper therefore must be hereby marked advertisement solely to indicate this fact. method should be available. Sometimes, an evaluation method must be developed before breeding for that objective can become routine.

The most common approach to breeding these crops is sometimes called "complementary hybridization." Poehlman (1987) presents a brief outline, and Simmonds (1979) discusses additional information. The parent clones of each cross are chosen such that the weaknesses of one are matched by the strengths of the other, with the hope that a few of their offspring will have the strengths of both parents and none of the weaknesses. Because the parent clones are highly heterozygous, tremendous segregation is apparent in the seedling population. The challenge then is to identify from among the thousands of seedlings the few that have potential as new cultivars. Evaluation typically is stepwise, with the number of selected genotypes decreasing in each step while the number of vegetatively propagated plants of each increases. In the first step, selection is based on the performance of the original seedling plant and is limited to highly heritable traits that can be evaluated quickly and inexpensively. In the second phase of evaluation, a small unreplicated trial is used to study the performance of selections more carefully. Typically, 10 plants of each selection are included. In the third stage of evaluation, advanced selections are grown in a replicated trial and compared to standard cultivars. Often, other breeders and a few progressive growers plant the best of these selections to see how they perform in their locations while yield trials are in progress. The very best selection is released as a new cultivar. For tree crops, selection is typically in only two phases to reduce the time for release of a new cultivar: evaluation of the original seedling and evaluation in a replicated trial. Janick et al. (1983) discussed procedures for releasing and legally protecting new cultivars.

Because the complementary hybridization approach is repeated generation after generation, the method is essentially phenotypic recurrent selection, with selected seedlings from one generation serving as parents of the next. Although only additive gene effects respond to selection over cycles, in any one generation, the breeder can take advantage of all types of genetic variance, because desirable gene combinations can be fixed by clonal propagation.

Plant breeding is a numbers game. Because the frequency of truly superior seedlings is quite low, breeders typically compensate by making as many crosses as the resources of the program allow. They grow a sample of seedlings from each cross sufficiently large to allow them to assess the potential of that cross. For example, the Oregon State Univ. (OSU), Corvallis, hazelnut (Corylus avellana L.) breeding program plants $\approx 5000$ new seedlings in the field each year. We average $\approx 50$ to 60 crosses each year and believe that 80 to 100 seedlings allow us to determine the potential of a cross. Selections that prove to be superior parents are crossed with additional genotypes.

A second approach, the modified backcross method, involves a series of crosses and is used to transfer a single trait from a wild or unadapted source to something with cultivar potential. In contrast to the backcross method as used for inbred lines, a different "recurrent parent" is used in each backcross generation to avoid inbreeding. A good illustration of this approach is the pedigree of the scab-resistant 'McShay' apple (Mehlenbacher et al., 1988). Another good example of the modified backcross method is the incorporation of the dayneutral character from Fragaria virginiana ssp. glauca Wats into modern California strawberry cultivars (Bringhurst et al., 1989). Because of the high degree of heterozygosity of any parent clone, it is not possible to recreate the same clone with one added gene using the backcross method. For agronomic and vegetable crops, the release of a backcross-derived cultivar typically involves five or six backcross generations. In fruit and nut crops, the number of generations is often considerably less. Half-high blueberries, for example, are first-genera- 
tion interspecific hybrids (Luby et al., 1986). 'Nova Easygro' apple, which combines scab resistance from the Russian selection R127407A with large fruit size, is the result of only two backcross generations (Crowe, 1975). 'Rouville' apple, which combines scab resistance from Malus atrosanguinea Schneid. 804 with large fruit size, is similarly the product of only two backcross generations (Rouselle and Fortin, 1983). The majority of almond [Prunus dulcis (Miller) D. A. Webb] cultivars are essentially selections from the wild. Following interspecific hybridization [e.g., with Prunus webbii (Spach) Vieh. and peach], selections with cultivar potential can be recovered after one or two backcrosses to P. dulcis Miller [T. Gradziel, personal communication (pers. comm.)]. At the other extreme, when gall mite (Cecidophyopsis ribis Westw.) resistance was transferred from gooseberry (Ribes grossularia L.) to black currant (R. nigrum L.), selections with cultivar potential were not recovered until the $\mathrm{BC}_{7}$ generation (Brennan et al., 1993).

In contrast to other crops, breeders of vegetatively propagated crops tend to view heterozygosity per se as desirable, and search out and use many diverse parents.

\section{DISEASE RESISTANCE}

Host plant resistance is an effective means of controlling many diseases and is a major component in disease management programs. As environmental concerns continue and as fewer pesticides are available for use on minor crops, resistant cultivars will become more important.

Disease resistance is an objective of most breeding programs, and Simmonds (1979) discusses the topic from a breeder's perspective. More accurately, disease resistance is one of many objectives. The pathogens that affect fruit and nut crops include fungi, bacteria, viruses, and mycoplasma-like organisms. Sources of resistance are known for many diseases but not for others. The severity of certain diseases varies from one region to another, and from year to year. The emphasis that a breeder places on disease resistance reflects its importance in that area. Classical disease resistance breeding has been most effective when it is a joint effort between a plant breeder and a plant pathologist. Unfortunately, close cooperation is the exception rather than the rule, and many plant breeders have found themselves working alone.

A seedling population segregating for resistance can be evaluated in the greenhouse, growth chamber, nursery, field, or even in vitro. Dayton et al. (1983) reviewed methods for fruit and nut crops. More reliable or more efficient methods are constantly being developed or refined. If disease resistance is a top priority, it becomes a primary screen and only resistant seedlings are planted in the field. For diseases that are less serious, a secondary screening of promising selections quantifies the level of resistance and this information is included in the release notice of the new cultivar. A high level of resistance is often not necessary, but extreme susceptibility to any pathogen can doom an otherwise outstanding cultivar (Simmonds, 1979).

Resistance can be evaluated in various ways, as the examples will illustrate. A knowledge of the pathogen and its life cycle is essential. In some applications, seedlings are artificially inoculated in the greenhouse or growth chamber under controlled conditions. In others, seedlings are exposed to inoculum under field conditions, where disease pressure and uniformity are hoped to be adequate to determine the level of resistance. In some cases, resistance can only be assessed in the field in certain "test years" when conditions are appropriate for disease development. In field trials, artificial inoculum is sometimes applied to supplement natural inoculum, and "spreader rows" of a susceptible cultivar can also be used to boost the natural level of inoculum.

Greenhouse and growth chamber tests have replaced field evaluation for disease resistance in many cases. They usually give more reliable, repeatable results and allow early elimination of susceptible seedlings. The development of these screening methods involves a knowledge of the "disease triangle" (Fig. 1). For disease to develop, a susceptible host, a virulent pathogen, and the appropriate environmental conditions must coincide. The conditions provided in these tests generally duplicate those that are ideal for disease development under

\section{The Disease Triangle}

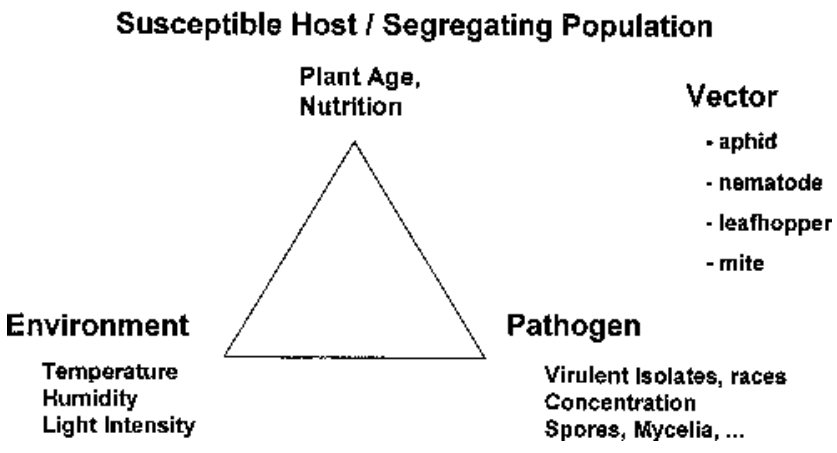

Fig. 1. The disease triangle. A susceptible host, a virulent pathogen, and appropriate environmental conditions must coincide for disease to develop. A vector also may be necessary.

natural conditions. The host plant must be at the appropriate growth stage and in reasonably good health. A virulent race or isolate of the pathogen must be present at an effective concentration and in the right form (spores, mycelia, etc.). Carborundum may be needed to abrade the leaf surface. The appropriate environmental conditions must be present for infection and symptom expression to occur; temperature and humidity often are critical factors. Symptom expression may occur hours, days, weeks, or even months after infection. For eastern filbert blight [Anisogramma anomala (Peck) E. Müller] of hazelnut, cankers do not develop until 15 months after infection (Stone et al., 1992).

Disease resistance is generally categorized as either vertical or horizontal (van der Plank, 1982), although not all plant-pathogen interactions fit nicely into either category. Vertical resistance genes in the host confer a high level of resistance that is often expressed as a hypersensitive response. In segregating populations, seedlings can be classified as either resistant or susceptible. There are often several races of the pathogen; the race can be identified by inoculating a series of cultivars called "differential hosts" that carry known resistance alleles. For diseases that have been studied extensively, a gene-forgene relationship between resistance genes in the host and virulence genes in the pathogen has been demonstrated (Sidhu, 1987). Vertical resistance genes are fairly simple to manipulate through breeding because segregation ratios can be predicted. Many vertical resistance genes have been transferred from wild or unadapted material using the modified backcross method. When a new race of the pathogen appears, the resistance is no longer effective. The development of new races is a concern primarily with rusts, mildews, and other air-borne fungi, as new races of these pathogens can spread quickly. Similarly, new biotypes of aphid vectors also can spread quickly. For soil-borne fungi, bacteria, and nematodes, spread is usually localized; thus, vertical resistance genes are more likely to provide long-term control (Simmonds, 1979) if precautions are taken to minimize spread by people.

In contrast to vertical resistance, horizontal resistance is under polygenic control. A segregating population typically shows a continuous distribution for disease reaction. Highly susceptible and highly resistant plants can be present, while most plants show an intermediate reaction. Resistance is often expressed as a slow rate of lesion development or reduced sporulation. The level of horizontal resistance in a population can be increased by recurrent selection in the absence of vertical resistance genes.

Both vertical and horizontal resistance have been used successfully by breeders. In fact, in practice it is not necessary to understand the mechanism of resistance. What is necessary is the presence of genetic variation for disease resistance and the ability to select for it (Simmonds, 1979).

Control of some diseases is more easily accomplished by breeding for resistance to the vector rather than to the pathogen itself. Examples of this approach include breeding for resistance to the raspberry aphid 
(Amphorophora idaei Börner in Europe and A. agathonica Hottes in North America) to control mosaic virus, breeding for resistance to the sharpnosed leafhopper (Staphytopius magdalensis Peoc.) to control blueberry stunt mycoplasma, and breeding for gall mite resistance in black currant to slow the spread of reversion virus. Many viruses are also nematode-vectored (e.g., fanleaf virus in grape, tomato ringspot in Prunus), and in these instances, nematode resistance might be more easily accomplished than virus resistance.

\section{CLASSICAL APPROACH TO BREEDING FOR DISEASE RESISTANCE}

\section{Small fruit}

Strawberry (Fragaria Xananassa Duch.). Virus tolerance is a requirement of cultivars on the West Coast. Four major viruses affect strawberry: strawberry mottle, strawberry crinkle, strawberry vein banding, and strawberry mild yellow edge. Disease pressure is particularly severe in British Columbia, where the susceptible cultivar Hood cannot be grown and where the virus tolerance of 'Totem' is a major factor in its long-term success (Daubeny et al., 1993). Virus tolerance is evaluated in the field in British Columbia. Under severe pressure, tolerant seedlings remain symptomless while susceptible seedlings show virus symptoms within 1 year of field planting.

Red stele, caused by Phytophthora fragariae Hickman, is a problem in most wet sites, although hill culture and other cultural practices can minimize its impact. Screening for red stele resistance is a major part of the programs at Corvallis and Beltsville, Md., and Scott et al. (1984) reviewed the programs' status and procedures. Resistance has been evaluated using benches in a cool greenhouse and inoculation with a mixture of isolates. High humidity and cool temperatures are critical, especially after inoculation. Testing procedures using growth chambers have been developed that allow screening on a year-round basis (John Maas and Gene Galletta, pers. comm.). Several races of the pathogen have been identified, and a gene-for-gene relationship between host and pathogen genes has been documented. A series of differential hosts with known resistance alleles is used to identify races of the fungus (van de Weg et al., 1993a, 1993b). It is critical that only pathogen-free plants be planted in the field to avoid spread of new races.

Other root-rot diseases that are a concern in the eastern United States include verticillium root rot (V. albo-atrum Reinke \& Berth. and $V$. dahliae Kleb.) and black root rot caused by Pythium and Rhizoctonia. Resistance to these pathogens is evaluated by planting seedlings and replicating yield trials in sites with heavy, wet, infested soils.

Foliar diseases that include leaf spot [Mycosporella fragariae (Schw.) Lind] and leaf scorch [Diplocarpon earliana (Ell. \& Ev.) Wolf] are also problems in the eastern United States and Canada. Some breeders select for resistance when the disease is present; in Quebec, seedlings are inoculated in the greenhouse and advanced selections are retested in the greenhouse (S. Khanizadeh, pers. comm). Resistance to fungal pests of strawberry are generally quantitative and partially dominant so that some resistance is transmitted in the first generation (Galletta, pers. comm.)

Anthracnose (Colletotrichum acutatum Simmonds) is a problem in the southern states where it affects plants and fruit (Ballington and Milholland, 1993). In Arkansas, resistant seedlings are selected in the field where inoculum is abundant and uniformly distributed (J.N. Moore, pers. comm.). Growth chamber inoculations have been used in North Carolina (Ballington and Milholland, 1993). Resistance is quantitative, with moderate narrow-sense and high broad-sense heritability (Gupton and Smith, 1991).

Raspberry and blackberry (Rubus spp.). Resistance to the mosaic virus complex that affects red raspberry has been very effectively accomplished by breeding for resistance to the raspberry aphid vector rather than to the viruses themselves. Keep (1989) reviewed the resistance sources and procedures used against the European raspberry aphid (Amphorophora idaei Börner). In the United Kingdom, four aphid biotypes are known, but some resistance genes confer resistance to all known biotypes. The same testing procedures are used in British Columbia for resistance to the North American raspberry aphid ( $A$. agathonica Hottes). Two years ago, a new biotype was discovered there that was able to overcome the resistance of recent introductions. However, resistance to the new biotype has been discovered in native Rubus idaeus var. strigosus, and it appears that collection and use of several resistance genes holds considerable promise for the future (Daubeny and Stary, 1982; Daubeny et al., 1992).

Resistance to root rot caused by Phytophthora fragariae var. rubi is an objective in the Pacific Northwest. The level of resistance in common cultivars, as determined by field tests, was reported by Barritt et al. (1979). Using greenhouse inoculations, Bristow et al. (1988) found resistance in the native North American raspberry Rubus idaeus var. strigosus Michx., particularly those accessions collected in wet sites, and also in the salmonberry Rubus spectabilis Pursch. Efforts are underway to incorporate these additional sources of resistance. Duncan et al. (1987) identified three races of the fungus, but all North American isolates were of race 3. Recent work was described by Kennedy and Duncan $(1991,1993)$.

Keep (1989) and Hall (1990) described sources of resistance to several other diseases and pests for red raspberry and for blackberry, respectively. Interspecific transfer of disease resistance is common in Rubus.

Blueberry (Vaccinium corymbosum L.). Several diseases affect blueberry. Two of the most severe in North Carolina are stem blight and blueberry stunt (Ballington et al., 1993). Other important diseases include stem canker caused by Botryosphaeria corticis (Demaree \& Wilcok) Arx \& Muller, anthracnose caused by Colletotricum gloeosporioides (Penz.) Penz \& Sacc., shoestring virus, red ringspot, mummy berry caused by Monilinia vaccinii-corymbosi (Reade) Honey, and leaf mottle virus.

Stem blight caused by Botryosphaeria dothidea (Mouq. ex Fr.) Ces $\&$ deNot. is especially severe on young plants when the fungus enters through pruning wounds. Creswell and Milholand (1987) and Cline et al. (1993) describe methods for evaluating cultivar susceptibility. While pure $V$. corymbosum appears to be uniformly susceptible, resistance appears to be present in $V$. angustifolium Ait. and $V$. ashei Reade. Resistance is quantitative, partially dominant, and sufficiently heritable so that response to phenotypic recurrent selection is expected. Many progenies must be grown to obtain resistant selections.

Breeding for resistance to the blueberry stunt mycoplasma is being conducted by breeding for resistance to the vector, the sharpnosed leafhopper, as there is no known source of resistance to the mycoplasma itself. Sources of resistance to feeding and oviposition have been identified (Etzel and Meyer, 1986; Meyer and Ballington, 1990). Resistance is a recessive trait in V. elliottii Chapman and a partially resistant trait in $V$. ashei.

Stem canker also is a serious problem in many production regions. Milholland and Galletta (1969) developed screening methods, and Ballington et al. (1993) have identified eight races to date. Propagation from canker-free sources and isolation of new plantings from old canker-infected plants is effective at minimizing disease incidence.

Red ringspot virus susceptibility was evaluated in New Jersey under field conditions. Degree of symptom expression after several years of field exposure indicates that resistance is polygenic and that 'Earliblue' and several numbered selections appear to transmit resistance (Ehlenfeldt et al., 1993).

Grape (Vitis spp. L.). Powdery mildew caused by Uncinula necator (Schwein.) Burr is a serious disease problem of both wine and table grapes in all production regions. Some American Vitis species and interspecific hybrids involving these species are resistant, as are numerous French hybrids with commercial value (Boubals, 1961). Resistance is an objective of breeding programs in New York (Cornell Univ., Geneva), Arkansas (Univ. of Arkansas), California [U.S. Dept of Agriculture (USDA) and SunWorld], and Minnesota (Univ. of Minnesota). As is the case with mildews in other crops, there is some controversy as to the reliability of screening very young seedlings in the greenhouse. Reliability increases with plant age. Both California programs eliminate a high percentage of seedlings based on greenhouse screening under shadecloth. Only highly resistant seedlings are planted and further evaluated in the vineyard. The high level of resistance of some French hybrids is being transferred to seedless table grapes, and in some cases, resistance may be due to a single dominant 
gene. In Arkansas, only highly susceptible seedlings are eliminated in the greenhouse; additional notes are recorded in the vineyard. In Minnesota, seedlings, $\approx 30 \mathrm{~cm}$ tall, are transplanted to an unsprayed nursery adjacent to an infested vineyard in May. Seedlings are rated for susceptibility from late July to September, and only resistant seedlings are transplanted to the vineyard the following spring. At Geneva, all seedlings are transplanted and grown in an unsprayed vineyard.

Other important grape diseases include black rot caused by Guignardia bidwellii (Ellis) Viala et Ravaz, downy mildew caused by Plasmopara viticola de Bary, and Pierce's disease caused by the bacterium Xylella fastidiosa. In general, seedlings are rated in unsprayed vineyards. Resistance is derived from native North American species (Alleweldt et al., 1991; Barrett, 1955; Jabco et al., 1985; Mortensen, 1968, 1977; Mortensen et al., 1977). Phylloxera and nematodes, including the dagger nematodes, which vector grape fanleaf virus, are serious pests, but no good screening methods have yet been developed.

\section{Tree fruit}

Apple (Malus $\times$ domestica Borkh.). Considerable effort has gone into breeding disease-resistant apples. Phytophthora crown rot and fire blight are the most serious diseases that affect rootstocks. Scab, cedarapple rust, powdery mildew, and fire blight are the four most serious diseases of scion cultivars.

The objectives, standards, and flow chart of the Geneva apple rootstock breeding program were described by Cummins and Aldwinckle (1983). Resistance to phytophthora crown rot caused by several Phytophthora spp. and fire blight are considered essential in new rootstock selections. Sequential inoculation with these two pathogens eliminates $90 \%$ of the seedlings. Phytophthora resistance screening is by flooding 10-day-old seedlings to the soil line with suspensions of zoospores of mixed pathogenic isolates. This inoculation results in foot and hypocotyl infections and death of susceptible seedlings (Aldwinckle and Cummins, 1974; Watkins and Werts, 1971).

Fire blight, caused by the bacterium Erwinia amylovora (Burr.) Winslow et al., is a serious problem of rootstocks and scions. Resistance is assessed in seedlings when they are 8 to 10 weeks old by injecting their shoot tips with $10^{6}$ to $10^{7}$ cells of a mixture of virulent isolates. Seedlings are discarded if lesions exceed $30 \%$ of the seedling's height. Reinoculation confirms their resistance. Gardner et al. (1980) demonstrated that the high level of resistance in $M . \times$ robusta (Carriere) Rehder No. 5 and M. ×sublobata (Dipp.) Rehder PI 286613 appeared to be oligogenic, and it is for these sources of resistance that differential response of bacterial isolates has been detected (Norelli et al., 1984). In scion cultivar breeding, resistance is polygenic and a mixture of isolates is used for inoculation.

The development of scion cultivars resistant to apple scab caused by Venturia inaequalis (Cke.) Wint. was summarized by Crosby et al. (1992). Subsequent research identified six loci for qualitative resistance, with dominant alleles $\mathrm{V}_{\mathrm{f}}, \mathrm{V}_{\mathrm{m}}, \mathrm{V}_{\mathrm{r}}, \mathrm{V}_{\mathrm{bj}}, \mathrm{V}_{\mathrm{b}}$, and $\mathrm{V}_{\mathrm{a}}$ designated according to their origin (Williams and Kuc, 1969). Of these, $V_{f}$ from Malus floribunda Siebold ex Van Houte 821 has been used most widely. 'Nova Easygro' and 'Nova Spy' carry $\mathrm{V}_{\mathrm{r}}$; 'Rouville' and four recent Russian releases carry $\mathrm{V}_{\mathrm{m}}$ and are thus susceptible to race 5 . Races of the scab fungus have been known for some time, and the recent discovery in Europe of a race able to overcome the $V_{f}$ gene (Parisi et al., 1993) is causing increased interest in other sources of resistance. If seedlings with a few sporulating lesions are classified as resistant, greenhouse inoculations of populations carrying the $V_{f}$ gene segregate 1 susceptible : 1 resistant. In the Geneva program, only seedlings with no sporulating lesions are kept.

Cedar-apple rustcaused by Gymnosporangiumjuniperi-virginianae Schw. is a problem in eastern North America where the eastern red cedar (Juniperus virginiana L.), the alternate host of the fungus, is present. Greenhouse inoculations are used in the Geneva program, and seedlings that show pycnia development are eliminated (Aldwinckle etal., 1977). Resistance is conferred by two dominant genes (Aldwinckle et al., 1977; Chen and Korban, 1987). When dominant alleles are present at both loci, pycnia formation is suppressed. In New Jersey, eastern red cedar trees are planted alongside apple seedlings and natural infection allows identification and elimination of the most susceptible seedlings.

A very high level of powdery mildew [caused by Podosphaera leucotricha (Ell. \& Ev.) Salm.] resistance has been reported in several small-fruited species (Dayton, 1977; Gallott et al., 1985; Knight and Alston, 1969; Korban and Dayton, 1983), and for these sources, it is possible to screen young seedlings in the greenhouse. Many of these sources appear to carry single dominant genes for resistance. Most apple breeders, however, have preferred to use the polygenic resistance present in several apple cultivars. Resistant cultivars tend to transmit resistance, and ratings of potential parents give a good indication of their value as parents (Brown, 1959). However, greenhouse inoculations are not considered reliable for evaluating polygenic resistance. Many breeders eliminate highly susceptible seedlings in the nursery, while others wait until they are growing in the field (Mihatch and Mildenberger, 1967).

Fruit rots [bitter rot caused by Glomorella cingulata (Ston.) Spauld. \& Schrenk and black rot caused by Botryosphaeria obtusa (Schw.) Cke.] are problems in the southern United States. Evaluation methods, which will be used to search for sources of resistance, are being developed at the Univ. of Arkansas. Sooty blotch and flyspeck are diseases for which there are no good sources of resistance.

Pear. Fire blight resistance is an objective of both the Kearneysville, W.Va., and Harrow, Ont., pear breeding programs (Hunter, 1993). The inoculation procedures are the same as for apple. In greenhouse tests, seedlings in which $>30 \%$ of the shoot length becomes infected are eliminated. In the field, injections of shoot tips with bacteria can supplement natural pressure for blossom and shoot blight. Resistance is quantitatively inherited with a narrow sense heritability of $52 \%$ and is not associated with poor fruit quality (Bell et al., 1976). Subsequent research in Italy and France has confirmed these results (Bagnara et al., 1993, 1994), and this seems to be the case regardless of the source of resistance (Layne et al., 1968). A few pear genotypes transmit a high degree of susceptibility and are believed to carry a dominant gene for sensitivity (Thompson et al., 1975). Several resistant cultivars have been released from both the Kearneysville and the Harrow programs. No differential response of isolates has been reported (Bell et al., 1990; Hunter and Bonn, 1994).

Peach (Prunus persica L.) Batsch. Bacterial spot caused by Xanthomonas campestris pv. pruni is a problem common to the eastern states and is evaluated by planting seedlings and selections in the field (Werner et al., 1986). Several alternative methods have been proposed, including greenhouse inoculations, detached leaf tests, and others (Civerolo and Keil, 1976; Daines and Hough, 1951; Hammerschlag, 1988; Randhawa and Civerolo, 1985), but breeders have declined to use them because they are not sufficiently reliable or worth the effort.

Brown rot caused by Monilinia fructicola (Wint.) Honey is a problem in most areas and is particularly severe on clingstone peaches and nectarines. Not much resistance is available in cultivars. Brown rot resistance from the Brazilian cultivar Bolinha is being used in the cling peach programs at the Univ. of California-Davis and the Univ. of Arkansas. Resistance appears to be limited to the skin, as the disease spreads quickly if the skin is punctured (T. Gradziel and J.N. Moore, pers. comm.). Fruit susceptibility is evaluated by placing a drop of spores on the skin and measuring the diameter of the developing lesion.

Canker caused by Cytospora leucostoma (Pers.) Sacc. is a problem in northern areas, particularly those with fluctuating temperatures in midwinter. Results using the wound-freeze method developed by Scorza and Pusey (1984) appear to correlate well with field observations. Resistance has been reported in 'Yennoh', 'NJC1', and 'Encore' (Chang et al., 1989).

Apricot (Prunus armeniaca L.). Bacterial spot is also a problem in apricot, and resistance is similarly based on field observations during epiphytotics. Layne (1966) noted that leaves and fruit can have different levels of resistance.

Plum pox or sharka virus is a serious problem in Europe. Based on field observations, cultivars are known to vary in severity of symptom expression (Dosba et al., 1991).

Sour cherry (Prunus cerasus L.). Cultivars differ in their susceptibility to cherry leaf spot caused by Blumeriella jaapii (Rehm) Arx. Artificial inoculation procedures can be used to identify the most 
susceptible seedlings and cultivars (Sjulin, 1989). At Michigan State Univ., greenhouse inoculations are used to eliminate the most susceptible seedlings (A. Iezzoni, pers. comm.)

Plum (Prunus salicina Lindl). Japanese plums encounter few problems in the major production area of California, but several diseases attack them in the humid southeastern United States. Resistance to most fungal diseases is rated based on survival and health in field plantings. Plum leaf scald caused by Xylella fastidiosa Wells et al. is of increasing concern in Florida, Georgia, and Alabama (Sherman et al., 1989, 1992). Plum pox virus is a severe problem of hexaploid cultivars in Europe. Bacterial spot causes lesions on leaves and fruit, and cankers on twigs. Evaluation methods are described by Topp et al. (1991, 1993a, 1993b).

Citrus. Disease problems of citrus are primarily rootstock problems. Soost and Cameron (1975) described evaluation methods for phytophthora root rot, citrus tristeza virus (CTV), and nematodes. Sweet orange trees on sour orange rootstocks frequently show quick decline when infected by CTV (Garnsey, 1985). The trifoliate orange, Poncirus trifoliata (L.) Raf., is resistant to CTV and transmits resistance to some hybrid progeny. Poncirus also has been the primary source of resistance to Phytophthora in intergeneric hybrids (Gmitter et al., 1992). In addition, it is resistant to citrus nematode, Tylenchulus semipenetrans Cobb (Barrett, 1985).

\section{Tree nuts}

Walnut (Juglans regia $L$.). Blackline disease is a serious problem in California, where most orchards consist of Persian scion cultivars (Juglans regia) grafted to either northern California black walnut $[J$. hindsii (Jeps.) Rehder] or 'Paradox' hybrid (J. hindsii $\times$ J. regia) rootstocks. Blackline also has been observed in Europe (McGranahan and Catlin, 1987). Briefly, blackline is caused by the cherry leaf roll virus (CLRV), to which the Persian walnut is tolerant but J. hindsii and 'Paradox' are hypersensitive. The pollen-borne virus enters through flowers during pollination and spreads systemically in the tolerant scion. When the virus meets the hypersensitive rootstock, a layer of cells dies, leading to a "black line" at the graft union. The hypersensitive response of $J$. hindsii, J. major (Torr. ex Sitsgr.) Heller, and the eastern black walnut (J. nigra) is conferred by a single dominant gene (Dosba et al., 1989; Dosba and Germain, 1993; Mircetich and Rowhani, 1984). Two approaches are being followed in California and France. The first is the development of vigorous, tolerant clonal rootstocks and the other is the development of resistant scion cultivars by transferring the hypersensitive response of the black walnut by backcrossing.

In both approaches (rootstock and scion), segregating populations are evaluated to determine which selections are hypersensitive and which are tolerant. This determination can be made in 1 year. Persian rootstocks are grafted with scions of the selections in question, and the rootstocks are inoculated with CLRV using a bark patch graft. If a black line develops at the graft union, the scion is considered hypersensitive. If no black line develops and enzyme-linked immunosorbent assay reveals that the scion is infected, the selection is considered tolerant. Several vigorous, tolerant rootstock clones [(J. nigra $\times J$. regia $) \times J$. regia and (J. major $\times J$. regia $) \times J$. regia] that are late-leafing and have strong apical dominance are currently being tested in Bordeaux, France, and no further crosses are planned (Germain et al., 1994). The long-term backcrossing programs to develop hypersensitive scion cultivars are now in the $\mathrm{BC}_{3}$ generation and already the seedlings resemble wild populations of $J$. regia. They differ from leading cultivars mainly in shell thickness. The California program is using the $J$. hindsii source of hypersensitivity, while the French program is using the J. nigra and J. major sources. One or perhaps two more generations of backcrossing will be needed to recover thinshelled seedlings with cultivar potential. If the virus overcomes the resistance, then both scion and rootstock will be tolerant.

Bacterial blight caused by Xanthomonas campestris pv. juglandis is a problem in France and California. Late-leafing cultivars often escape blight and late-leafing is a priority trait in both programs, but nuts of these selections also are late-maturing. Field notes are taken on leaves and young fruit in early July and again in mid-August when infected, necrotic nuts drop. Shoots are inspected for cankers during winter. As disease escape is common, more stringent tests have been developed for assessing resistance.

Woeste et al. (1992) described inoculation and rating procedures for leaves and nuts, and detected differences in leaf symptoms and nut abscission. A more elaborate protocol is used in France where the disease is more severe (E. Germain, pers. comm.). Three trees of each selection are planted at a spacing of $1.5 \times 2.0 \mathrm{~m}$ under a mist system installed $2 \mathrm{~m}$ above ground level. For each tree, two nozzles $50 \mathrm{~cm}$ on either side of the tree emit 70 liters. $\mathrm{h}^{-1}$. Leaves and shoots are inoculated with a bacterial suspension (one completely colonized petri dish per liter of distilled water) at the end of the day to avoid hot, dry periods at the beginning of the second season in the field when shoots are 15 to $20 \mathrm{~cm}$ long. For the next 10 to 12 days, the mist is on $24 \mathrm{sec}$ every $20 \mathrm{~min}$ (to runoff) from 9:00 AM to 5:00 PM. Symptoms are noted 1 month after inoculation, and again 1 month later. Shoots are inspected for the presence of cankers after leaf fall. The inoculations are repeated a second year to verify the results. 'Adams 10' (resistant), 'Franquette' (intermediate), and 'Hartley' (susceptible) are included as the check cultivars.

Hazelnut (Corylus avellana L.). Eastern filbert blight caused by Anisogramma anomala (Peck) E. Müller is a serious disease that threatens Oregon's hazelnut industry. Its history, symptoms, and life cycle were reviewed by Mehlenbacher et al. (1994). Although pruning and chemicals slow the spread of the disease, genetic resistance offers the best long-term solution to the problem. Two sources of resistance are being used in the OSU hazelnut breeding program: immunity from 'Gasaway' and horizontal resistance within C. avellana. A high level of resistance was recently detected in several Corylus species (Coyne and Mehlenbacher, 1994) and will be incorporated in future crosses.

The old pollinizer cultivar Gasaway is heterozygous for a single dominant gene that confers immunity (Mehlenbacher et al., 1991), but it has many undesirable traits as well. A modified backcross program is being used to combine immunity with acceptable nut characteristics. Seedlings from the first backcross generation have begun to fruit. It appears that an immune selection with acceptable precocity, yield, and kernel quality will be obtained from the $\mathrm{BC}_{1}$ generation.

Standard cultivars vary in their level of susceptibility, and this variability can be quantified by counting the number and length of cankers that develop following exposure of potted trees under wooden frames topped with infected wood (Pinkerton et al., 1993).

Pecan [Carya illinoinensis (Wangenh) K. Koch]. Scab caused by Cladosporium caryigenum (Ell. et Lang.) Gottwald is the most serious disease of pecan. An unusually wet year resulted in scab infection in the USDA pecan breeding plots in Brownwood and College Station, Texas, in 1993 and allowed leaf and fruit infection to be rated on 33,000 seedlings and their parents. Heritability of resistance was estimated to be 54\% (Thompson and Grauke, 1994). The frequency of highly resistant cultivars and selections was low, but $\approx 20$ highly resistant genotypes with good nut quality were identified. The resistance appears to have been contributed by several unrelated parents. Advanced selections from the USDA program are being evaluated for susceptibility in Florida.

\section{MAPPING AND MAS}

Introductory comments. Molecular markers, including isozymes and DNA markers [restriction fragment length polymorphisms (RFLPs), random amplified polymorphic DNA (RAPDs), and others], have been useful in many situations relevant to applied plant breeding. Dendrograms constructed from molecular marker data indicate the degree of similarity of species and accessions and in general agree well with classifications based on morphological traits or geographic origin. Linkage maps have been constructed for many economically important crops, and maps for related crops have been compared when these maps have been constructed with common markers (e.g., Bonierbale et al., 1988). Most computer programs used for linkage map construction are designed for use with self-pollinated crops in which the parents are homozygous inbred lines. Recombination percentages are estimated from recombinant inbred lines or segregating $\mathrm{F}_{2}$ or $\mathrm{BC}_{1}$ seedling populations. These programs have been directly useful in less polymorphic crops (e.g., peach and citrus) in which the 
mapping populations have been generated in a two-step procedure. In the first step, highly heterozygous $F_{1}$ hybrids are obtained from wide crosses (often interspecific, or even intergeneric in the case of Citrus). The mapping population is produced by either selfing an $\mathrm{F}_{1}$ plant or backcrossing it to one of the parents. Data from these segregating $\mathrm{F}_{2}$ or $\mathrm{BC}_{1}$ populations are suitable for analysis with these standard programs. A concern in the use of wide crosses in the construction of linkage maps is that the amount of recombination between linked loci in these crosses may be considerably less than in crosses within the species of interest.

For most clonally propagated crops, however, parent clones are highly heterozygous and a tremendous amount of segregation can be observed in the first-generation intraspecific offspring, and simultaneous segregation of many loci allows linkage map construction. Procedures for map construction in this "double pseudotestcross" situation were described by Hemmat et al. (1994). Briefly, most loci will segregate $1: 1$, allowing construction of a linkage map for each parent of the cross. Loci that segregate 3:1 allow the maps for the two parents to be aligned.

Fruit and nut crops have additional advantages in mapping and molecular marker research. Their perennial nature allows use of the same plants over a period of years, during which many additional markers can be placed on the map. Clonal propagation allows several laboratories to use the same mapping populations in their research. The European tree-fruit mapping projects, which involve six laboratories in four countries, are using the same populations at all sites.

$M A S$. The identification of markers or "tags" tightly linked to genes of interest makes it possible to select for desired alleles indirectly. MAS appears to have promise in the development of disease-resistant cultivars. Suggested uses of molecular tags in fruit and nut breeding include: following resistance alleles in several crosses over several generations, identifying seedlings likely to be resistant in the absence of the pathogen, constructing pyramids of resistance genes without the need for progeny testing, and more rapidly eliminating the donor parent genome in a modified backcross program.

Some traits that show a continuous distribution in a segregating population may actually be controlled by a small number of loci (Paterson et al., 1991), and genetic analysis using molecular markers in conjunction with a linkage map can, in these instances, allow identification of the number and location of these loci. Bulk segregant analysis using extreme phenotypes (typically the upper and lower 5\%) is a powerful tool for identifying the number of major loci controlling the trait, although this procedure overestimates the effects of the identified loci (Lander and Botstein, 1989; Michelmore et al., 1991). If the number of quantitative trait loci (QTLs) is small (1-3), the trait can be handled as if it were qualitative. However, the application of MAS for yield and other traits that are truly quantitative is unclear (Dudley, 1993). In all cases, there is concern about the usefulness of molecular markers in different populations and the expression of alleles when transferred from one genetic background to another. MAS will supplement but not replace traditional breeding methods, and will likely be most useful for traits that are controlled by few loci and that are either expensive or difficult to evaluate by classical methods (Lande, 1992). For some pathogens, it may be difficult to provide conditions that provide uniform infection for precise screening-but such conditions must be provided when identifying marker loci. Theoretically, MAS is superior to conventional methods if the fraction of the additive variance explained by the markers exceeds the narrow sense heritability of the trait (Dudley, 1993). However, most traits in fruit and nut crops are highly heritable (Hansche, 1983).

\section{Mapping and MAS in small fruit}

In strawberry, a map has been constructed in a diploid population at the Univ. of New Hampshire (Davis, 1993). The map contains 80 markers, most of which are RAPDs. It is not yet known how useful this map will be for working at the octoploid level, but researchers hope that "tags" can be developed for red stele resistance genes in cooperation with the USDA Small Fruits Laboratory in Beltsville.

In blueberry, a map constructed from a diploid population was recently published (Rowland and Levi, 1994). The map contains $>70$ markers, most of which are RAPDs. Michigan State Univ. researchers are using markers on this map to locate resistance to shoestring virus in a tetraploid population (J. Hancock, pers. comm.). A cooperative project is also underway in North Carolina and New Jersey to find markers for resistance to the sharpnosed leafhopper with an emphasis on the rabbiteye blueberry source (J. Ballington, pers. comm.).

A linkage map for grape was recently constructed at Geneva (B. Reisch, pers. comm.). The map contains 500 markers, most of which are RAPDs, and was constructed from a population of complex parentage: (Vitis rupestris $\times V$. cineria) $\times V$. vinifera. One of the markers is closely linked to a powdery mildew resistance locus. Several other populations in an unsprayed vineyard are segregating for resistance to powdery and downy mildew and black rot, and the search for molecular markers linked to alleles for resistance to these three diseases is in progress. North American species carry genes for resistance to the major diseases and pests. Because grape species intercross freely, a great wealth of genetic diversity is available for mapping and use in future breeding. At the Univ. of California-Davis, the objective of the grape rootstock breeding program is to develop rootstocks resistant to phylloxera, fanleaf virus, and several species of nematodes. The lack of reliable screening methods for these pests currently is a serious limitation.

\section{Mapping and MAS in tree fruit}

A linkage map for apple was recently published (Hemmat et al., 1994) and research is in progress in Europe. In subsequent work at Geneva, N.Y., markers for fruit color and mildew immunity have been located in the 'Rome Beauty' $x$ 'White Angel' cross, and markers for scab resistance genes $\left(V_{f}\right.$ and $V_{r}$ ) and columnar growth habit have been identified in other populations (Conner et al., 1994; Cheng et al., 1994, Hemmat et al., 1994; N. Weeden, pers. comm.). Durham and Korban (1994) discovered a marker for a minor gene for scab resistance from M. floribunda 821. The recent report of a race of scab able to overcome the $V_{f}$ resistance gene (Parisi et al., 1993) indicates that single-gene resistance is unlikely to be durable. Pyramids of $V_{f}$ and other genes will likely be incorporated in future cultivars, and MAS will facilitate the identification of seedlings carrying multiple resistance alleles. With the recent map-based cloning of a disease resistance gene in tomato (Martin et al., 1993), breeders hope that map-based cloning of resistance genes also will be possible in apple in the next few years. Once cloned, these resistance genes could then be inserted into otherwise superior but susceptible cultivars.

Stone fruit. The European Prunus mapping project began in Fall 1993 and is a 4-year project involving six research institutes in four countries. In the first phase, $\mathrm{F}_{2}$ populations from crosses of 'Earlygold' peach $x$ 'Texas' almond and 'Stella' $x$ a cherry species are being used to construct a basic map of 200 RFLP markers (Arús et al., 1994). Then, 11 progenies (four of peach, three of cherry, two of almond, and two of plum) will be used to assign important traits to the overall map. To my knowledge, no mapping work is in progress in North America for sweet cherry, sour cherry, or apricot.

With its small genome size and large number of simply inherited traits, peach is a logical choice for genetics studies. A linkage map for peach was recently published for a North Carolina $F_{2}$ population segregating for many morphological and isozyme traits (Chaparro et al., 1994). The map contains 85 loci (mostly RAPDs), including markers for nectarine skin, red leaf pigmentation, and upright (pillar) growth habit. Isozyme studies have shown that peach has fewer polymorphisms than other tree fruit (Byrne, 1990). Plans at North Carolina State Univ. (NCSU) include mapping genes for bacterial spot resistance in an $\mathrm{F}_{2}$ population from a cross of the highly susceptible 'O'Henry' with resistant 'Sentinel', and a continuation of the search for markers near the nectarine locus. A linkage map for peach also has been developed at Clemson Univ. using populations from USDA (Kearneysville), NCSU, and Institut National de la Recherche Agronomique (Bordeaux, France). Their map currently contains $\approx 60$ markers (40RFLPs, 15RAPDs, and 5 morphological traits) (Rajapakse et al., 1994; V. Baird, pers. comm.). Only $\approx 20 \%$ of the markers are polymorphic in all of the crosses investigated. The USDA Fruit Laboratory, Kearneysville, is interested in mapping genes associated 
with fruit quality. Applications of such markers would be for quick recovery of acceptable fruit quality (recurrent parent phenotype) when introgressing disease resistance genes from almond, wild peach species, or inferior cultivars (R. Scorza, pers. comm.).

A linkage map for an $\mathrm{F}_{2}$ interspecific population (dwarf peach 54P455 x 'Padre' almond) has been constructed at Univ. of CaliforniaDavis (Foolad et al., 1994). To date, $\approx 100$ RFLP markers have been assigned to nine linkage groups, six of which are large. Current research efforts involve bulk segregant analysis to assign important traits to the map (F. Bliss, pers. comm.). Possible applications include breeding for nematode resistance (root knot, ring, lesion, and dagger) because testing is time-consuming and difficult.

Citrus fruit. There is considerable activity in mapping and searching for molecular markers linked to important traits in citrus with an emphasis on rootstock diseases and pests. In the Florida and Univ. of California-Riverside programs, the trifoliate orange has been a source of many desirable traits. These traits include resistance to CTV, Phytophthora, and the citrus nematode. Two linkage maps were recently constructed using RFLPs (Durham et al., 1992; Jarrell et al., 1992) for a backcross population, and subsequent work with RAPDs has increased the number of loci to between 200 and 300. Resistance to tristeza virus appears to be conferred by a single dominant gene, and markers closely linked to resistance have been identified in both programs (F. Gmitter and M. Roose, pers. comm.). Research in Florida showed that resistance to the citrus nematode, expressed as the number of nematodes per gram fresh weight of root, showed a continuous distribution. However, when the most resistant and most susceptible individuals in the population were used in bulk segregant analysis, a marker linked to a major gene associated with resistance was identified (Ling et al., 1994). Researchers at Univ. of California-Riverside plan to map resistance to Phytophthora, but the lack of precise and repeatable methods for assessing resistance is a major stumbling block. Additional applications of MAS in citrus include mapping genes for growth habit and cold and salt stress from the trifoliate orange. Markers could also assist in more rapid recovery of acceptable fruit quality in backcrosses to cultivated types. Following hybridization with Poncirus, marginally edible fruit can be obtained in the third backcross generation.

\section{Mapping and MAS in nut crops}

Almond. Researchers in Spain have constructed a map for the almond cross 'Ferragnes' $x$ 'Tuono' (Arús et al., 1994). At present, it contains 150 markers (124 RFLPs, 15 RAPDs, and 7 isozymes) and is based on a population of 60 seedlings. Seedlings in this population are being evaluated for self-compatibility, bloom date, and percentage of double kernels. The workers hope that markers will be identified for these traits. Bulk segregant analysis in two other almond populations revealed one RAPD marker linked to the bitter kernel trait but none linked to self-compatibility. In an 'Earlygold' peach $\mathrm{x}$ 'Texas' almond $\mathrm{F}_{2}$ population, 50 markers already have been assigned and the map is now being expanded to 250 markers (Arús et al., 1994). This map and the similar peach $\mathrm{x}$ almond map developed at the Univ. of CaliforniaDavis likely will be applicable to both peach and almond and facilitate the transfer of useful genes, such as self-fertility from peach to almond and Cytospora canker resistance from almond to peach. Since selffertility in almond includes self-compatibility as well as flower structures that encourage self-pollination, self-fertility cannot be considered a single-gene trait. Almond cultivars are not far removed from the wild and thus only a few backcross generations should be necessary to recover cultivar potential (T. Gradziel, pers. comm.).

A linkage map for walnut was recently constructed using RFLP markers in a $(\mathrm{J}$. hindsii $\times \mathrm{J}$. regia $) \times J$. regia backcross population of 63 seedlings (Fjellstrom and Parfitt, 1994). Woeste et al. (1994) identified 60 RAPD markers specific to the black walnut in this cross in the hope that they would be useful in recovering "English" types quickly in backcrosses to transfer CLRV resistance to J. regia. A marker linked to the dominant gene for CLRV hypersensitivity also was identified (G. McGranahan, pers. comm.). Precocity, however, is of overriding importance in determining which seedlings are used as parents of the next backcross generation.
To my knowledge, there is currently no mapping work in progress for hazelnut, but research is in progress to identify RAPD markers linked to the dominant gene from 'Gasaway' for immunity to eastern filbert blight. Bulk segregant analysis is being used in a population segregating 1:1 for resistance and susceptibility. Detection of a RAPD marker closely linked to immunity would allow quick elimination of susceptible seedlings.

In pistachio, a RAPD marker linked to sex expression was reported recently (Hormaza et al., 1994).

\section{Appropriate uses and cost-effectiveness of MAS}

Clearly, considerable effort is being devoted to developing linkage maps for fruit and nut crops and in identifying molecular markers linked to traits of economic importance. MAS will be most useful for traits controlled by few loci; application of MAS for improving traits that are truly quantitative is in doubt (Dudley, 1993); The extent to which MAS will be used in practice depends on relative cost and expected return compared to conventional methods (Dudley, 1993), and application will, at least initially, be limited to simply inherited traits that are difficult or expensive to measure. Also, it is essential that the identified markers be useful in several crosses over several generations rather than to the one cross already evaluated. The following applications in breeding disease-resistant fruit and nut cultivars appear most appropriate: 1) identifying seedlings likely to be resistant either in the absence of the pathogen (due to quarantine regulations in some instances) or when reliable conventional methods are difficult or expensive, 2) constructing pyramids of resistance genes without the need for progeny testing (if multiple races of the pathogen exist), and 3) more rapidly eliminating the donor parent genome in a modified backcross program. The routine application of MAS requires careful analysis of the relative costs and benefits of the conventional and MAS approaches.

\section{TRANSFORMATION}

Transformation, the insertion of a foreign gene into a plant cell, is a powerful tool in the struggle to develop disease-resistant plant cultivars. The inserted genes can originate from viruses, bacteria, fungi, animals, other plant species, or the same crop species. Inserted genes can be sense or antisense constructs. Much progress has been made in the last few years, as reviewed by Fisk and Dandekar (1994), Hammerschlag and Litz (1992), Martin (1994), and Schuerman and Dandekar (1994). Agrobacterium-mediated transformation has been used most commonly, largely because of its efficiency. In most cases, our inability to regenerate plants from single cells is the limiting factor. In other cases, selecting transformed cells or killing Agrobacterium with antibiotics has a detrimental effect on cell survival. Transformation via particle bombardment also is being used. The frequency of stable transformation is generally lower than with Agrobacterium, and although the need for regeneration may be circumvented if meristems are the target tissue, the likelihood of recovering chimeras needs to be addressed. The number of known genes that confer disease resistance in higher plants is still limited but growing steadily. Likewise, the number of tissue-specific promoters is limited but also increasing.

Transformed cells are most often selected by incorporating antibiotic resistance. When exposed to the antibiotic, untransformed cells die and transformed cells survive and multiply. The neomycin phosphotransferase (NPTII) gene, which confers kanamycin resistance, is most commonly used. Also commonly incorporated is the gus gene, which encodes $B$-glucuronidase and allows its detection and assessment of expression patterns.

In many crops, regeneration has been possible only with seed- or seedling-derived material, as woody plants are particularly recalcitrant. Transformation of seedlings allows incorporation of genes from other organisms and greatly expands the opportunities for genetic improvement of plants. Since seedlings are nearly always inferior to their parent clones, further breeding would generally be needed to recover genotypes with cultivar potential. Although transformation of seedlings would allow incorporating new genetic material in the development of new cultivars, it would have a negligible impact on the 
time required for release of a new cultivar. For fruit crops that are sold by cultivar name (e.g., apple, pear, and wine grape), transformation would be a much more powerful tool if we were able to add one or a few genes to correct the deficiencies of otherwise excellent cultivars. In crops where transformation of clonal selections is possible, regeneration procedures have been genotype-specific. Even when clonal selections are transformed, field testing is essential to verify that the desired trait is expressed and that unintended changes have not occurred.

Expression in transgenic plants may be affected by many factors, including the construct, the number of insertions, the location of the insertion(s), and the promoter. Somaclonal variation also may result from in vitro culture. In a conventional breeding program, gene transfer via controlled pollination is a minor part of the overall program; evaluation of the resulting seedlings is the time-consuming part. Claims of the speed with which new cultivars can be developed by transformation imply that neither field evaluation nor propagation are needed before introducing a new cultivar; such exaggerated claims are unfortunately numerous in the popular press and in refereed publications.

The public is still apprehensive about the products of genetic engineering. Dozens of field tests of transgenic plants are now in progress and one product, the Flavr-Savr tomato, is now on the market. It will be interesting to see how well this product is accepted. Some publicity is needed to get a new cultivar off to a good start, and the Flavr-Savr tomato has had its share of attention. In the end, the marketplace will decide if the addition of one gene to a cultivar justifies tripling the price of the product. Breeders have long operated under the assumption that the worth of a new cultivar depends on the combination of traits that it expresses, not on the breeding method used in its development.

\section{Transformation-Small fruit}

Transformation of some strawberry cultivars is now routine, but procedures must be developed for each cultivar (R. Martin, pers. comm.) In British Columbia, the transformation work is for resistance to strawberry mild yellow edge virus. Some private companies are attempting to insert genes that confer resistance to other viruses. Transformation work is also in progress in several other locations (Haymes and Davis, 1993; James et al., 1990; Nehra et al., 1990; Nehra and Wallin, 1992). Transformation of red raspberry has been accomplished (Hassan et al., 1993), and research is underway at Agritope (Cohen et al., 1994; Mathews et al., 1994) and in England (Graham et al., 1990) to improve the efficiency of transformation. Black currant also has been transformed (Graham and McNicol, 1991). Research is underway at Beltsville and at Michigan State Univ. to transform blueberry, but efforts to date have not been successful (J. Hancock, pers. comm.). Transgenic cranberry (Vaccinium macrocarpon Aiton) plants have been produced by particle bombardment (Serres et al., 1992).

Embryogenic cultures of the grape cultivar Chancellor have been transformed using the biolistic method (Hebert et al., 1993). In transformed lines, the gus gene has been stably expressed in $>50$ plants for two years after bombardment (B. Reisch, pers. comm.). This work is now being expanded to include a Trichoderma endochitinase gene that confers fungal resistance. A cooperative effort between USDA labs in Kearneysville and Fresno, Calif., successfully transformed somatic embryos from zygotic embryos of a seedless $X$ seedless cross using a combination of the biolistic method and Agrobacterium. Bombardment with uncoated gold particles wounded the tissue, which was followed by cocultivation with Agrobacterium (Scorza et al., 1994a). Fourteen kanamycin-resistant plants with expressed gus were recovered. It should be possible to transform grape clones from somatic embryos using recently developed regeneration methods. Some transformation work with fanleaf virus coat protein is ongoing in France, and additional research is in progress in Israel. In grape, somatic embryos appear to arise from single cells on the tissue surface, and recent progress in regeneration is expected to allow transformation of superior clones (Emershad and Ramming, 1994). Baribault et al. (1990) and Mullins et al. (1990) also reported grape transformation.

\section{Transformation-Tree fruit}

Transformation work in apple at Cornell Univ. has emphasized fire blight resistance conferred by lytic peptides from the giant silk moth. The clonal rootstock M.26 has been transformed (125 lines) with the attacin gene. Transformed plants were resistant in greenhouse tests using bacterial injections with a hypodermic needle and are now growing in the field. The scion cultivar Gala also has been transformed, and 20 lines are now being evaluated. Transformation work is now being expanded to include chitinase genes from Trichoderma that confer resistance to fungi and the coat protein gene of tomato ringspot virus. Cultivars other than Gala are being transformed. Transformation of 'McIntosh' with antisense constructs for polygalacturonase and ACC synthase also is planned. The transformation system in apple is well developed using primarily Agrobacterium and some particle bombardment. Work at Univ. of California-Davis has produced apple lines that carry the insect resistance genes from Bacillus thuringiensis (A. M. Dandekar, pers. comm.), and research is in progress in Illinois to transform apple with the coat protein of apple mosaic virus. Additional work was described by James et al. (1989, 1994), and DeBondt et al. (1994).

Pear has not yet been successfully transformed, although success was recently reported for quince (Cydonia oblonga L.) rootstocks (Bunnag et al., 1994). Regeneration is difficult for most cultivars. The USDA laboratory in Kearneysville and the Geneva station are planning a cooperative effort to transform pears with the attacin gene which confers resistance to fire blight (R. Bell, pers. comm.).

There are several successful reports of transformation of peach (Scorza et al., 1995). All have used seeds or seedling-derived explants. More effective methods are needed to kill the Agrobacterium without harming the transformed plant tissue. Hammerschlag and Smigocki (1994) inserted a cytokinin biosynthesis gene into peach using a previously published protocol (Hammerschlag et al., 1989; Smigocki and Hammerschlag, 1991). Ye et al. (1994) used particle bombardment to transform callus tissue, but no transformed plantlets were recovered. Researchers at Kearneysville plan to bombard meristems in vitro either with or without subsequent cocultivation with Agrobacterium. Transformation of 'Nemaguard', 'Nemared', and 'Flordaguard' rootstocks with the coat protein of the tomato ringspot virus, the cause of stem pitting, is in progress. These rootstocks are seedpropagated, so transformation of individual clones is not necessary.

Austrian researchers have transformed apricot seedlings with the coat protein of the plum pox virus (Laimer et al., 1992).

Plum was recently transformed at Kearneysville using seed hypocotyl explants (Mante et al., 1991; Scorza et al., 1994b). Four plants carrying the papaya ringspot virus coat protein gene and 10 with the plum pox coat protein gene have been regenerated. Papaya ringspot virus is closely related to plum pox virus, which is the primary concern in stone fruit. Of the first four transformants, one expressed resistance or tolerance in greenhouse testing. The other 10 transformants are currently being tested. In the future, this research will be expanded to include tomato ringspot virus.

Transformation research in citrus has emphasized coat proteinmediated resistance to tristeza virus in rootstocks and scions (Moore et al., 1992, 1993). Transformation of nucellar seedlings of sour orange using Agrobacterium has been successful in Florida, and the resulting plants will soon be evaluated for virus resistance. Durability of virus resistance is a concern in all tree crops. Recent results with particle bombardment are encouraging (F. Gmitter, pers. comm.). Nucellar seedlings faithfully reproduce superior clones, but the resulting trees are juvenile. Transformation of adult tissue would be highly desirable, but inability to regenerate adult tissues is a major obstacle.

Among tropical tree fruits, much work has been done in papaya (Carica papaya L.) to insert the coat protein gene of papaya ringspot virus (PRV) using particle bombardment. Regenerated transgenic plants showed a range of reactions to PRV (Fitch et al., 1990; Tennant et al., 1994).

\section{Transformation-Tree nuts}

Walnut can now be transformed routinely using seed-derived 
somatic embryos (McGranahan et al., 1988, 1990). Lines transformed with the coat protein gene from CLRV were not hypersensitive to the virus. Rootability genes from Agrobacterium rhizogenes have been inserted, and one tree from this work is now growing in the lathhouse. Transgenic plants expressing insecticidal proteins from Bacillus thuringiensis have been produced and show resistance to the navel orangeworm (Amyelois transitella Walker) (Dandekar et al., 1994). Plans include transformation of Paradox rootstock with a $B t$ gene that confers nematode resistance, and possibly chitinase and other genes for resistance to fungal pathogens (McGranahan, pers. comm.). Pecan was recently transformed using the walnut somatic embryo protocols (McGranahan et al., 1993).

To my knowledge, there are no reports of successful transformation of hazelnut, although regeneration from somatic embryos is possible from seed-derived material (Perez et al., 1983; Rodriguez et al., 1989). Recently at OSU, three clones were regenerated from petioles or leaf disks (Yu, 1993). These results indicate that transformation and regeneration should be possible in the near future.

\section{Comments}

In several fruit crops (e.g., apple, pear, wine grape), industries have been built around a few cultivars. In these cases, traditional methods have had little impact, as the industry is reluctant to adopt new cultivars. The ability to insert one or a few genes to correct the deficiencies of the leading cultivars would be particularly attractive. The chief limitation of the backcross method in self-pollinated crops (as well as its greatest strength) is its predictability. This would also be the case with transformation in clonally propagated crops, as it would allow insertion of one gene to correct a deficiency in an otherwise good cultivar. This feature is also a limitation, because there would be no other improvements.

If we accept 'Delicious' as the ultimate apple, then transformation alone might be sufficient for improving the crop. However, the rapid acceptance of new apple cultivars from New Zealand and Japan demonstrates that improvements in quality are possible with traditional methods and that customers are willing to pay more for superior quality. Thus, it appears that, even for apple, transformation alone would be too conservative an approach for genetic improvement.

Several concerns are familiar to those working on transformation (and in fact all areas of research), yet the tendency not to publish negative results makes the public unaware of their existence. Many attempts to transform crop plants have failed. Many transformed lines do not express the trait that was sought, and many transformed lines express the inserted gene but are sufficiently abnormal to prevent them from being commercially acceptable; rarely is the latter discussed in the literature (Belknap et al., 1994). Abnormalities are often attributed to somaclonal variation from the tissue culture process, the site of gene insertion, the number of copies inserted, etc. Yet researchers (W.G. Dougherty, pers. comm.) working with tobacco at OSU and with apple at Geneva (H.S. Aldwinckle, pers. comm.) believe strongly that these abnormalities are due to the constructs themselves. That is, regardless of the number of copies inserted or their location, a construct always produces the same abnormal phenotype. As with traditional plant breeding, transformation also may be a "numbers game" that requires the use of several constructs and regeneration of several lines from each to find one that expresses the desired trait at a high level yet has no other adverse effects. Experienced researchers estimate that 50 to 100 transformed lines must be regenerated using several different constructs to be reasonably sure of obtaining at least one that meets the objectives of the program. Screening, multiplication, and field testing are the time-consuming phases.

Durability, breadth of protection, and stability also are concerns. Because tree fruit and nut crops are particularly long-lived, resistance must protect an orchard for several decades. If several races of the pathogen are known, resistance should be provided against all races in the area. Research is in progress to investigate the effect of a sexual cycle on stability using the gus gene in plum (R. Scorza, pers. comm.).

With tree crops, needs are different for rootstocks than for scion cultivars. Resistance to soil-borne fungi and viruses are needed in new rootstocks. With certain precautions, these pathogens do not move quickly; thus, single dominant gene resistance likely will provide sufficiently durable resistance. Growers change scion cultivars much more readily than they do rootstocks.

Concern for human safety has prompted the U.S. Food and Drug Administration (FDA) to require approval of each transgenic event. Transgenic rootstocks should be less controversial, as rootstocks are not consumed. Field testing of transgenic walnuts requires that the trees be emasculated each year and that all fruit be bagged on the tree before maturity. There also is some controversy about virus-resistant plants actually allowing recombination and thus the creation of new races of the pathogen (Greene and Allison, 1994).

Over time, we will learn how and when to best use these tools in conjunction with traditional breeding methods, as well as which health, safety, and environmental concerns are justifiable.

\section{CONCLUDING COMMENTS}

Disease resistance is an important objective of most fruit and nut crop breeding programs, as these crops are affected by a wide array of pathogens whose importance varies over locations and time. Each breeding program appropriately has unique objectives, priorities, and standards of acceptability. In some cases, a high level of resistance is required, while in other cases a moderate level is adequate. Extreme susceptibility to any pathogen is unacceptable. For some diseases, sources of resistance and methods of quickly and reliably identifying resistant seedlings are well documented and currently in use. This is not the case for other diseases. In a few instances, disease control has resulted from breeding for resistance to the vector rather than to the pathogen. Breeders are using vertical and horizontal resistance, and a few pathogen-host plant interactions show a gene-for-gene relationship. Many resistant cultivars have been developed by classical methods and released in spite of this difficulty.

Marker-assisted selection and transformation are new and powerful tools in the development of new disease-resistant cultivars. In spite of their "minor crop" status, fruit and nut crops have received considerable attention in both areas. These tools complement, but do not replace, classical plant breeding. Bulk segregant analysis appears to offer great potential for finding RAPD markers linked to alleles for disease resistance, even for traits that initially appear to be quantitative. Once molecular "tags" have been identified for resistance alleles, selection based on these tags becomes possible. However, feasibility and cost-effectiveness also must be considered, particularly when use of these tools involves a shift of resources away from traditional breeding rather than the use of supplemental resources for these additional activities.

The productive life of a new planting and the useful life of a new cultivar are also important considerations. For strawberry and other crops in which plantings are of short duration, resistance that delays disease development by a few weeks might be important. However, orchards of tree crops are often productive for several decades, and durable disease resistance is essential. The life expectancy of a new cultivar also varies markedly among crops. A strawberry cultivar might be obsolete a decade after release, while a new apple rootstock might be in the early stages of adoption by the industry at that time. Most peach cultivars also are short-lived; rarely is the same cultivar planted when an old orchard is removed. For crops in which the life expectancy of a new cultivar is short, a heavy reliance on transformation of currently important clones would be unwise, as those cultivars might well be obsolete by the time adequate field testing of the transformants had been accomplished.

As an applied plant breeder, my mission is to develop new and improved cultivars that meet the needs of the industry I serve and, indirectly, those of the public at large. The promotion of biotechnology at the expense of traditional plant breeding over the past several years has been detrimental to all concerned, as it is only by working together that we will be able to realize the full potential of all of the available tools. The greatest strides in past efforts to develop disease-resistant cultivars have been made by plant breeders and plant pathologists working together. In the future, a team effort should include a molecular geneticist as well. Such a team could discuss the needs of the industries, the strengths and weaknesses of current cultivars, the 
genetic resources available to meet those needs, and the evaluation methods available. They could then use the genes and the tools that are most appropriate and cost-effective in that situation.

\section{Literature Cited}

Aldwinckle, H.S. and J.N. Cummins. 1974. Familial differences in reaction to flood inoculation of young apple seedlings by zoospore suspension of Phytophthora cactorum. Proc. 19th Intl. Hort. Congr., Warsaw 1A:328.

Aldwinckle, H.S., R.C. Lamb, and H.L. Gustafson. 1977. Nature and inheritance of resistance to Gymnosporangium juniperi-virginianae in apple cultivars. Phytopathology 67:259-266.

Alleweldt, G., P. Spiegel-Roy, and B. Reisch. 1991. Grapes (Vitis) In: J.N. Moore and J.R. Ballington, Jr. (eds.). Genetic resources of temperate fruit and nut crops. Acta Hort. 290:291-337.

Arús, P., R. Messeguer, M. Viruel, K. Tobutt, E. Dirlewanger, F. Santi, R. Quarta, and E. Ritter. 1994. The European Prunus mapping projectProgress in the almond linkage map. Euphytica 77:97-100.

Bagnara, G.L., L. Rivalta, M. Laghi, and R. Quarta. 1994. Relationship between fire blight resistance and some traits in pear. Acta Hort. 367:2226.

Bagnara, G.L., L. Rivalta, M. Laghi, R. Quarta, and P. Lecomte. 1993. Cross combinations for fire blight resistance in pear. Acta Hort. 338:369-374.

Ballington, J.R. and R.D. Milholland. 1993. Screening strawberries for resistance to Colletotrichum acutatum in North Carolina. Acta Hort. 348:442448.

Ballington, J.R., S.O. Rooks, R.O. Milholland, W.O. Cline, and J.R. Meyer. 1993. Breeding blueberries for pest resistance in North Carolina. Acta Hort. 346:87-94.

Baribault, T.J., K.G.M. Skene, P.A. Cain, and N.S. Scott. 1990. Transgenic grapevines: Regeneration of shoots expressing B-glucuronidase. J. Expt. Bot. 41:1045-1049.

Barrett, H.C. 1955. Black rot resistance of the foliage on seedlings in selected grape progenies. Proc. Amer. Soc. Hort. Sci. 66:220-224.

Barrett, H.C. 1985. Hybridization of Citrus and related genera. Fruit Var. J. 39:11-16.

Barritt, B.H., P.C. Crandall, and P.R. Bristow. 1979. Breeding for root rot resistance in red raspberry. J. Amer. Soc. Hort. Sci. 104:92-94.

Belknap, W.R., D. Corsini, J.J. Pavek, G.W. Snyder, D.R. Rockhold, and M.E. Vayda. 1994. Field performance of transgenic Russet Burbank and Lemhi Russet potatoes. Amer. Potato J. 71:285-296.

Bell, R.L., J. Janick, R.H.Zimmerman, and T. van der Zwet. 1976. Relationship between fire blight resistance and fruit quality in pear. HortScience 11:500502.

Bell, R.L., T. van der Zwet, W.G. Bonn, B. Thibault, and P. Lecomte. 1990. Environmental and strain effects on screening for fire blight resistance. Acta Hort. 273:343-353.

Bonierbale, M.W., R.L. Plaisted., and S.D. Tanksley. 1988. RFLP maps based on a common set of clones reveal modes of chromosomal evolution in potato and tomato. Genetics 120:1095-1103.

Boubals, D. 1961. Étude des causes de la resistance des vitacées à l'oidium de la vigne-Uncinula necator (Schw.) Burr.-et de leur mode de transmission héréditaire. Ann. Amélioration Plantes 11:401-500.

Brennan, R.M., P.G. Lanham, and R.J. McNicol. 1993. Ribes breeding and research in the UK. Acta Hort. 352:267-275.

Bringhurst, R.S., H. Ahmadi, and V. Voth. 1989. Inheritance of the day-neutral trait in strawberries. Acta Hort. 265:35-41.

Bristow, P.R., H.A. Daubeny, T.M. Sjulin, H.S. Pepin, and G.E. Windom. 1988. Evaluation of Rubus germplasm for reaction to root rot caused by Phytophthora erythroseptica. J. Amer. Soc. Hort. Sci. 113:588-591.

Brown, A.G. 1959. The inheritance of mildew resistance in progenies of the cultivated apple. Euphytica 8:81-88.

Bunnag, S., R.C. Martin, D.W.S. Mok, and M.C. Mok. 1994. Towards genetic transformation of quince and pear. HortScience 29:561. (Abstr.)

Byrne, D.H. 1990. Isozyme variability in four diploid stone fruits compared with other woody perennial plants. J. Hered. 81:68-71.

Chang, L.S., A. Iezzoni, G. Adams, and G.S. Howell. 1989. Leucostoma persoonii tolerance and cold hardiness among diverse peach genotypes. J. Amer. Soc. Hort. Sci. 114:482-485.

Chaparro, J.X., D.J. Werner, D. O'Malley, and R.R. Sederoff. 1994. Targeted mapping and linkage analysis of morphological, isozyme, and RAPD markers in peach. Theor. Appl. Genet. 87:805-815.

Chen, H. and S.S. Korban. 1987. Genetic variability and the inheritance of resistance to cedar-apple rust in apple. Plant Pathol. 36:168-174.

Cheng, F., N. Weeden, and S. Brown. 1994. Molecular markers for fruit color in apple (Malus Xdomestica). HortScience 29:529. (Abstr.)

Civerolo, E.L. and H.L. Keil. 1976. Evaluation of Prunus spp. resistance to Xanthomonas pruni by artificial inoculation. Fruit Var. J. 30:17-18.
Cline, W., S. Rooks, R. Milholland, and J. Ballington. 1993. Techniques in breeding for resistance to blueberry stem-blight caused by Botryosphaeria dothidea. Acta Hort. 346:107-110.

Cohen, C., H. Mathews, V. Dewey, and R. Bestwick. 1994. Efficient plant regeneration from leaf and petiole explants in red raspberry. HortScience 29:514. (Abstr.)

Conner, P.J., S.K. Brown, and N.F. Weeden. 1994. Examination of quantitative trait loci in apple (Malus $\times$ domestica) using molecular markers. HortScience 29:529. (Abstr.)

Coyne, C.J. and S.A. Mehlenbacher. 1994. Resistance to eastern filbert blight in Corylus species and interspecific hybrids. HortScience 29:506. (Abstr.)

Creswell, T.C. and R.D. Milholland. 1987. Responses of blueberry genotypes to infection by Botryosphaeria dothidea. Plant Dis. 71:710-713.

Crosby, J.A., J. Janick, P.C. Pecknold, S.S. Korban, P.A. O'Connor, S.M. Ries, J. Goffreda, and A. Voordeckers. 1992. Breeding apples for scab resistance: 1945-1990. Fruit Var. J. 46:145-166.

Crowe, A.D. 1975. 'Nova Easygro' apple. Fruit Var. J. 29:76.

Cummins, J.N. and H.S. Aldwinckle. 1983. Breeding apple rootstocks. Plant Breeding Rev. 1:294-394.

Daines, R.H. and L.F. Hough. 1951. Artificial inoculation of peach seedlings with Xanthomonas pruni. Phytopathology 41:8-9. (Abstr.)

Dandekar, A.M., G.H. McGranahan, P.V. Vail, S.L. Uratsu, C.A. Leslie, and J.S. Tebbets. 1994. Low levels of expression of wild type Bacillus thuringiensis var. kurstaki cry1A (c) sequences in transgenic walnut somatic embryos. Plant Sci. 96:151-162.

Daubeny, H., F.J. Lawrence, and P.P. Moore. 1993. ‘Totem’ strawberry. Fruit Var. J. 47:182-184.

Daubeny, H., H.S. Pepin, and C.A. Levesque. 1992. Breeding for resistance to aphids and root rot in red raspberry. Acta Hort. 317:187-190.

Daubeny, H.A. and D. Stary. 1982. Identification of resistance to Amphorophora agathonica in the native North American red raspberry. J. Amer. Soc. Hort. Sci. 107:593-597.

Davis, T.M. 1993. Genetic mapping of the diploid strawberry using random amplified polymorphic DNA(RAPD) markers. Acta Hort. 348:439. (Abstr.)

Dayton, D.F. 1977. Genetic immunity to apple mildew incited by Podosphaera leucotricha. HortScience 12:225-226.

Dayton, D.F., R.L. Bell, and E.B. Williams. 1983. Disease resistance, p. 189215. In: J.N. Moore and J. Janick (eds.). Methods in fruit breeding. Purdue Univ. Press, West Lafayette, Ind

DeBondt, A., K. Eggermont, and W.F. Broekaert. 1994. Transgenic apple plants obtained by Agrobacterium-mediated gene transfer. Abstr. Fourth Intl. Congr. Plant Mol. Biol., Amsterdam, 19-24 June 1994. (Abstr.)

Dosba, F., F. Denise, P. Maison, G. Massonie, and J.M Audergon. 1991. Plum pox virus resistance of apricot. Acta Hort. 293:569-579.

Dosba, F. and E. Germain. 1993. Behaviour of the progeny of Juglans interspecific hybrids towards cherry leaf roll virus (CLRV). Acta Hort. 311:68-72.

Dosba, F., B. Nguyen, K. Mazy, and E. Germain. 1989. Etude dans le genre Juglans de different combinasions heterospecifique pour leur comportement vis-a-vis du cherry leaf roll virus (CLRV). Proc. 2nd colloque noyernoisetier, Programme de recherche agrimed, Bordeaux, France, 6-7 Sept. 1988. p. 3-16.

Dudley, J.W. 1993. Molecular markers in plant improvement: Manipulation of genes affecting quantitative traits. Crop Sci. 33:660-668.

Duncan, J.M., D.M. Kennedy, and E. Seemüller. 1987. Identities and pathogenicities of Phytophthora spp. causing root rot of raspberry. Plant Pathol. 36:276-289.

Durham, R.E. and S.S. Korban. 1994. Evidence of gene introgression in apple using RAPD markers. Euphytica 79:109-114.

Durham, R.E., P.C. Liou, F.G. Gmitter, Jr., and G.A. Moore. 1992. Linkage of restriction fragment length polymorphisms and isozymes in Citrus. Theor. Appl. Genet. 84:39-48.

Ehlenfeldt, M.K., A.W. Stretch, and A.D. Draper. 1993. Sources of genetic resistance to red ringspot virus in a breeding blueberry population. HortScience 28:207-208.

Emershad, R.L. and D.W. Ramming. 1994. Somatic embryogenesis and plant development from immature zygotic embryos of seedless grapes (Vitis vinifera L.). Plant Cell Rpt. 14:6-12.

Etzel, R.W. and J.R. Meyer. 1986. Resistance in blueberries to feeding and oviposition by the sharpnosed leafhopper Scaphtopius magdalensis (Provancher). J. Econ. Entomol. 79:1513-1515.

Fisk, H.J. and A.M. Dandekar. 1994. The introduction and expression of transgenes in plants. Scientia Hort. 55:5-36.

Fitch, M.M.M., R.M. Manshardt, D. Gonsalves, J.L. Slightom, and J.C. Sanford. 1990. Stable transformation of papaya via microprojectile bombardment. Plant Cell Rpt. 9:189-194.

Fjellstrom, R.G. and D.E. Parfitt. 1994. Development of an RFLP map for walnut. HortScience 29:529. (Abstr.)

Foolad, M.R., S. Arulsekar, and F. Bliss. 1994. Genetic linkage mapping in 
Prunus. HortScience 29:528. (Abstr.)

Gallott, J.C., R.C. Lamb, and H.S. Aldwinckle. 1985. Resistance to powdery mildew from small-fruited Malus cultivars. HortScience 20:1085-1087.

Gardner, R.G., J.N. Cummins, and H.S. Aldwinckle. 1980. Fire blight resistance in the Geneva apple rootstock breeding program. J. Amer. Soc. Hort. Sci. 105:907-912.

Garnsey, S.M. 1985. Virus and virus-like diseases of citrus and their impact on citrus production and germplasm selection. Fruit Var. J. 39:36-46.

Germain, E., F. Dosba, and E. Fos. 1994. Création de nouveaux porte-greffes de noyer "vigorisants" et tolerants au virus du cherry leaf roll. Proc. 8th Colloq. Fruit Research, Angers.

Gmitter, F.G., Jr., J.W. Grosser, and G.A. Moore. 1992. Citrus, p. 335-369. In: F.A. Hammerschlag and R.E. Litz (eds.). Biotechnology of perennial fruit crops. CAB Intl., Wallingford, U.K.

Graham, J. and R.J. McNichol. 1991. Regeneration and transformation of Ribes. Plant Cell Tissue Organ Cult. 24:91-95.

Graham, J., R.J. McNichol, and A. Kumar. 1990. Use of the GUS gene as a selectable marker for Agrobacterium-mediated transformation of Rubus. Plant Cell Tissue Organ Culture 20:35-39.

Greene, A.E. and R.F. Allison. 1994. Recombination between viral RNA and transgenic plant transcripts. Science 263:1423-1425.

Gupton, C.L. and B.J. Smith. 1991. Inheritance of resistance to Colletotrichum species in strawberry. J. Amer. Soc. Hort. Sci. 116:724-727.

Hall, H.K. 1990. Blackberry breeding. Plant Breeding Rev. 8:249-312.

Hammerschlag, F.A. 1988. Screening peaches in vitro for resistance to Xanthomonas campestris pv. pruni. J. Amer. Soc. Hort. Sci. 113:164-166.

Hammerschlag, F.A. and R.E. Litz (eds.). 1992. Biotechnology of perennial fruit crops. CAB Intl., Wallingford, U.K.

Hammerschlag, F.A., L.D. Owens, and A.C. Smigocki. 1989. Agrobacteriummediated transformation of peach cells derived from mature plants that were propagated in vitro. J. Amer. Soc. Hort. Sci. 114:508-510.

Hammerschlag, F.A. and A.C. Smigocki. 1994. Transgenic peach plants containing a cytokinin biosynthesis gene display altered growth in vitro and under greenhouse conditions. HortScience 29:454. (Abstr.)

Hansche, P.E. 1983. Response to selection, p. 154-171. In: J.N. Moore and J. Janick (eds.). Methods in fruit breeding. Purdue Univ. Press, West Lafayette, Ind.

Hassan, M.A., H.J. Swartz, G. Inamine, and P. Mullineaux. 1993. Agrobacterium tumefasciens-mediated transformation of several Rubus genotypes and recovery of transformed plants. Plant Cell Tissue Organ Cult. 33:9-17.

Haymes, K.M. and T.M. Davis. 1993. Agrobacterium-mediated transformation and regeneration of the diploid strawberry. Acta Hort. 348:440.

Hebert, D., J.R. Kikkert, F.D. Smith, and B.I. Reisch. 1993. Optimization of biolistic transformation of embryogenic grape cell suspensions. Plant Cell Rpt. 12:585-589.

Hemmat, M., N.F. Weeden, A.G. Manganaris, and D.M. Lawson. 1994. Molecular marker linkage map for apple. J. Hered. 85:4-11.

Hormaza, J.I., L. Dollo, and V.S. Polito. 1994. Molecular markers for early determination of sex of pistachio seedlings. HortScience 29:462. (Abstr.)

Hunter, D.M. 1993. Pear breeding for the 21st century-Program and progress at Harrow. Acta Hort. 338:377-383.

Hunter, D.M. and W.G. Bonn. 1994. Virulence of Erwinia amylovora strains on pear. HortScience 29:505. (Abstr.)

Jabco, J.P., W.B. Nesbitt, and D.J. Werner. 1985. Resistance of various classes of grapes to the bunch and muscadine forms of black rot. J. Amer. Soc. Hort. Sci. 110:762-765

James, D.J., A.J. Passey, and S.A. Baker. 1994. Stable gene expression in apple fruit tissues and segregation of transgenes in the progeny. Abstr. Fourth Intl. Congr. Plant Mol. Biol., Amsterdam, 19-24 June 1994. (Abstr.)

James, D.J., A.J. Passey, and D.J. Barbara. 1990. Agrobacterium-mediated transformation of the cultivated strawberry (Fragaria $\times$ ananassa Duch.) using disarmed binary vectors. Plant Sci. 69:79-94.

James, D.J., A.J. Passey, D.J. Barbara, and M. Bevan. 1989. Genetic transformation of apple (Malus pumila Mill.) using a disarmed Ti-binary vector. Plant Cell Rpt. 7:658-661.

Janick, J., R.E. Bagwill, and J.R. Nesbitt. 1983. Cultivar release and protection, p. 383-397. In: J.N. Moore and J. Janick (eds.). Methods in fruit breeding. Purdue Univ. Press, West Lafayette, Ind.

Jarrell, D.C., M.L. Roose, S.N. Traugh, and R.S. Kupper. 1992. A genetic map of citrus based on the segregation of isozymes and RFLPs in an intergeneric cross. Theor. Appl. Genet. 84:49-56.

Keep, E. 1989. Breeding red raspberries for resistance to diseases and pests. Plant Breeding Rev. 6:245-321.

Kennedy, D.M. and J.M. Duncan. 1991. Methods for assessing the resistance of raspberry genotypes to Phytophthora root rot. Plant Pathol. 40:387-394.

Kennedy, D.M. and J.M. Duncan. 1993. Occurrence of races in Phytophthora fragariae var. rubi on raspberry. Acta Hort. 352:555-562.

Knight, R.L. and F.H. Alston. 1969. Developments in apple breeding. Rpt. E. Malling Res. Sta. 1968:125-132.
Korban, S.S. and D.F. Dayton. 1983. Evaluation of Malus germplasm for resistance to powdery mildew. HortScience 18:219-220.

Laimer da Camara Machado, M., A. da Camara Machado, V. Hanzer, H. Weiss, F. Regner, H. Steinkellner, D. Mattanovich, R. Plail, E. Knapp, B. Kalthoff, and H. Katinger. 1992. Regeneration of transgenic plants of Prunus armeniaca containing the coat protein gene of plum pox virus. Plant Cell Rpt. 11:25-29.

Lande, R. 1992. Marker-assisted selection in relation to traditional methods of plant breeding, p. 437-451. In: H.T. Stalker and J.P. Murphy (eds.). Plant breeding in the 1990s. CAB Intl., Wallingford, U.K.

Lander, E.S. and D. Botstein. 1989. Mapping Mendelian factors underlying quantitative traits using RFLP linkage maps. Genetics 121:185-199.

Layne, R.E.C. 1966. Susceptibility of apricots to bacterial spot infection of foliage and fruit. Plant Dis. Rpt. 50:112-115.

Layne, R.E.C., C.H. Bailey, and L.F. Hough. 1968. Efficacy of transmission of fire blight resistance in Pyrus. Can. J. Plant Sci. 48:231-243.

Ling, P., F.G. Gmitter, Jr., L.W. Duncan, and S.Y. Xiao. 1994. Inheritance of citrus nematode resistance and its linkage with RAPD markers in citrus. HortScience 29:483. (Abstr.)

Luby, J.J., D.K. Wildung, C. Stushnoff, S.T. Munson, P.E. Read, and E.E. Hoover. 1986. 'Northblue', 'Northsky', and 'Northcountry' blueberries. HortScience 21:1240-1242.

Mante, S., P.H. Morgens, R. Scorza, J.M. Cordts, and A.M. Callahan. 1991. Agrobacterium-mediated transformation of plum (Prunus domestica L.) hypocotyl slices and regeneration of transgenic plants. Bio/Technology 9:853-857.

Martin, G.B., S.H. Brommonschenkel, J. Chunwongse, A. Frary, M.W. Ganal, R. Spivey, T. Wu, E.D. Earle, and S.D. Tanksley. 1993. Map-based cloning of a protein kinase gene conferring disease resistance in tomato. Science 262:1432-1436.

Martin, R.R. 1994. Genetic engineering of potatoes. Amer. Potato J. 71:347358.

Mathews, H., C. Cohen, W. Wagoner, J. Kellogg, V. Dewey, and R. Bestwick. 1994. Genetic transformation of red raspberry (Rubus idaeus L.) with a gene to control ethylene biosynthesis. HortScience 29:454. (Abstr.)

McGranahan, G.H. and P.B. Catlin. 1987. Juglans rootstocks, p. 411-450. In: R.C. Rom and R.F. Carlson (eds.). Rootstocks for fruit crops. Wiley, New York.

McGranahan, G.H., C.A. Leslie, A.M. Dandekar, S.L. Uratsu, and I.E. Yates. 1993. Transformation of pecan and regeneration of transgenic plants. Plant Cell Rpt. 12:634-638.

McGranahan, G.H., C.A. Leslie, S.L. Uratsu, and A.M. Dandekar. 1990. Improved efficiency of the walnut somatic embryo gene transfer system. Plant Cell Rpt. 8:512-516.

McGranahan, G.H., C.A. Leslie, S.L. Uratsu, L.A. Martin, and A.M. Dandekar. 1988. Agrobacterium-mediated transformation of walnut somatic embryos and regeneration of transgenic plants. Bio/Technology 6:800-804.

Mehlenbacher, S.A., J.N. Pinkerton, K.B. Johnson, and J.W. Pscheidt. 1994. Eastern filbert blight in Oregon. Acta Hort. 351:551-556.

Mehlenbacher, S.A., M.M. Thompson, and H.R. Cameron. 1991. Occurrence and inheritance of resistance to eastern filbert blight in 'Gasaway' hazelnut. HortScience 26:410-411.

Mehlenbacher, S.A., M.M. Thompson, J. Janick, E.B. Williams, F.H. Emerson, S.S. Korban, D.F. Dayton, and L.F. Hough. 1988. 'McShay' apple. HortScience 23:1091-1092.

Meyer, J.R. and J.R. Ballington. 1990. Resistance of Vaccinium spp. to the leafhopper Scaphytopius magdalensis (Homoptera:Cicadellidae). Ann. Entomol. Soc. Amer. 83:515-520.

Michelmore, R.W., I. Paran, and R.V. Kesseli. 1991. Identification of markers linked to disease resistance genes by bulked segregant analysis: A rapid method to detect markers in specific genomic regions using segregating populations. Proc. Natl. Acad. Sci. USA 88:9828-9832.

Mihatsch, H. and G. Mildenberger. 1967. Beiträge zur Vererbung der Mehltauresistenz bei Malus. III. Beobachtungen zum Frühselektionsproblem. Der Zuchter 37:25-32.

Milholland, R.D. and G.J. Galletta. 1969. Pathogenic variation among isolates of Botryosphaeria corticis on blueberry. Phytopathology 59:1540-1543.

Mircetich, S.M. and A. Rowhani. 1984. The relationship of cherry leaf roll virus and blackline disease of English walnut trees. Phytopathology 74:423-428.

Moore, G.A., A. Gutierrez-E., C. Jacono, M. McCaffery, and K. Cline. 1993. Production of transgenic citrus plants expressing the citrus tristeza virus coat protein gene. HortScience 28:513. (Abstr.)

Moore, G.A., C.C. Jacono, J.L. Neidigh, S.D. Lawrence, and K. Cline. 1992. Agrobacterium-mediated transformation of citrus stem segments and regeneration of transgenic plants. Plant Cell Rpt. 11:238-242.

Mortensen, J.A. 1968. The inheritance of resistance to Pierce's disease in Vitis. Proc. Amer. Soc. Hort. Sci. 92:331-337.

Mortensen, J.A. 1977. Segregation for resistance to black rot in selfed grape seedlings. Fruit Var. J. 31:59-60. 
Mortensen, J.A., L.H. Stover, and C.F. Balerdi. 1977. Sources of resistance to Pierce's disease in Vitis. J. Amer. Soc. Hort. Sci. 102:695-697.

Mullins, M.A., F.C.A. Tans, and D. Fasciotti. 1990. Agrobacterium-mediated genetic transformation of grapevines: Transgenic plants of Vitis rupestris Schelle and shoots of Vitis vinifera $\mathrm{L}$. Bio/Technology 8:1041-1045.

Nehra, M. and A. Wallin. 1992. Transient gene expression in strawberry (Fragaria $\times$ ananassa Duch.) protoplasts and the recovery of transgenic plants. Plant Cell Rpt. 11:105-108.

Nehra, S.N., R.N. Chibbar, K.K. Kartha, R.S.S. Datla, W.L. Crosby, and C. Stushnoff. 1990. Genetic transformation of strawberry by Agrobacterium tumefasciens using a leaf disk regeneration system. Plant Cell Rpt. 9:293298.

Norelli, J.L., H.S. Aldwinckle, and S.V. Beer. 1984. Differential host $\times$ pathogen interactions among cultivars of apple and strains of Erwinia amylovora. Phytopathology 74:136-139.

Parisi, L., Y. Lespinasse, J. Guillaumes, and J. Krüger. 1993. A new race of Venturia inaequalis virulent to apples with resistance due to the $V f$ gene. Phytopathology 83:533-537.

Paterson, A.H., S.D. Tanksley, and M.E. Sorrells. 1991. DNA markers in plant improvement. Adv. Agron. 46:39-90.

Perez, C., B. Fernandez, and R. Rodriguez. 1983. In vitro plantlet regeneration through asexual embryogenesis in cotyledonary segments of Corylus avellana L. Plant Cell Rpt. 2:226-228.

Pinkerton, J.N., K.B. Johnson, S.A. Mehlenbacher, and J.W. Pscheidt. 1993. Susceptibility of European hazelnut clones to eastern filbert blight. Plant Dis. 77:261-266.

Poehlman, J.M. 1987. Breeding field crops. 3rd ed. Van Nostrand Reinhold, New York.

Rajapakse, S., L.E. Belthoff, R. Scorza, R.E. Ballard, W.V. Baird, R. Monet, and A.G. Abbott. 1994. Genetic linkage mapping in peach. HortScience 29:529. (Abstr.)

Randhawa, P.S. and E.L. Civerolo. 1985. A detached-leaf bioassay for Xanthomonas campestris pv. pruni. Phytopathology 75:1060-1063.

Rodriguez, R., A. Rodriguez, A. Gonzalez, and C. Perez. 1989. Hazelnut (Corylus avellana L.), p. 127-160. In: Y.P.S. Bajaj (ed.). Biotechnology in agriculture and forestry. vol. 5. Trees II. Springer-Verlag, Berlin.

Rouselle, G.L. and C.N. Fortin. 1983. 'Rouville' et 'Richelieu': Deux cultivars de pommier résistant à la tavelure. Résumé des recherches. Agriculture Canada, Saint Jean-sur-Richelieu, Que. 12:288-289.

Rowland, L.J. and A. Levi. 1994. RAPD-based genetic linkage map of blueberry derived from a cross between diploid species (Vaccinium darrowi and V. elliottii). Theor. Appl. Genet. 87:863-868.

Schuerman, P.L. and A.M. Dandekar. 1994. Transformation of temperate woody crops: Progress and potentials. Scientia Hort. 55:101-124.

Scorza, R., J.M. Cordts, D.W. Ramming, and R.L. Emershad. 1994a. Transformation of grape (Vitis vinifera $\mathrm{L}$.) somatic embryos and regeneration of transgenic plants. J. Cellular Biochem. Suppl. 18A:102. (Abstr.)

Scorza, R., F.A. Hammerschlag, T.W. Zimmerman, and J.M. Cordts. 1995. Transformation of peach and plum. In: Y.P.S. Bajaj (ed.). Biotechnology in agriculture and forestry. Springer-Verlag, Berlin. (In press.)

Scorza, R. and P.L. Pusey. 1984. A wound-freezing inoculation technique for evaluating resistance to Cytospora leucostoma in young peach trees. Phytopathology 74:569-572.

Scorza, R., M. Ravelonandro, A.M. Callahan, J.M. Cordts, M. Fuchs, J. Dunez, and D. Gonsalves. 1994b. Transgenic plums (Prunus domestica L.) express plum pox virus coat protein gene. Plant Cell Rpt. 14:18-22.

Scott, D.H., A.D. Draper, and G.J. Galletta. 1984. Breeding strawberries for red stele resistance. Plant Breeding Rev. 2:195-214.

Serres, R., E. Stang, D. McCabe, D. Russel, D. Mahr, and B. McCown. 1992. Gene transfer using electric discharge particle bombardment and recovery of transformed cranberry plants. J. Amer. Soc. Hort. Sci. 117:174-180.
Sherman, W.B., B.L. Topp, and P.M. Lyrene. 1992. Breeding low-chill Japanese-type plums for subtropical climates. Acta Hort. 317:149-153.

Sherman, W.B., C.E. Yonce, W.R. Okie, and T.G. Beckman. 1989. Paradoxes surrounding our understanding of plum leaf scald. Fruit Var. J. 43:147-151.

Sidhu, G.S. 1987. Host-parasite genetics. Plant Breeding Rev. 5:393-433.

Simmonds, N.W. 1979. Principles of crop improvement. Longman, New York.

Sjulin, J.M. 1989. Expression of partial resistance to cherry leaf spot in cultivars of sweet, sour, duke, and European ground cherry. Plant Dis. 73:56-61.

Smigocki, A.C. and F.A. Hammerschlag. 1991. Regeneration of plants from peach embryo cells infected with a shooty mutant strain of Agrobacterium. J. Amer. Soc. Hort. Sci. 116:1092-1097.

Soost, R.K. and J.W. Cameron. 1975. Citrus, p. 507-540. In: J. Janick and J.N. Moore (eds.). Methods in fruit breeding. Purdue Univ. Press, West Lafayette, Ind.

Stone, J.K., K.B. Johnson, J.N. Pinkerton, and J.W. Pscheidt. 1992. Natural infection period and susceptibility of vegetative seedlings of European hazelnut to Anisogramma anomala. Plant Dis. 76:348-352.

Tennant, P.F., C. Gonsalves, K.S. Ling, M. Fitch, R. Manshardt, J.L. Slightom, and D. Gonsalves. 1994. Differential protection against papaya ringspot virus isolates in coat protein gene transgenic papaya and classically crossprotected papaya. Phytopathology 84:1359-1366.

Thompson, J.M., R.H. Zimmerman, and T. van der Zwet. 1975. Inheritance of fire blight resistance in Pyrus. I. A dominant gene Se causing sensitivity. J. Hered. 66:259-264.

Thompson, T.E. and L.J. Grauke. 1994. Genetic resistance to scab disease in pecan. HortScience 29:1078-1080.

Topp, B.L., W.B. Sherman, D.A. Huber, and S.B. Linda. 1993a. Combining abilities of five Japanese plum cultivars for resistance to Xanthomonas stem canker. HortScience 28:727-729.

Topp, B.L., W.B. Sherman, and R.E. Stall. 1991. Comparison of rating methods for bacterial spot resistance in Japanese-type plum. Fruit Var. J. 45:70-74.

Topp, B.L., W.B. Sherman, R.E. Stall, G.V. Minsavage, and C.J. Wilcox. 1993b. Comparison of greenhouse methods for assessing resistance to bacterial leaf spot in plum. J. Amer. Soc. Hort. Sci. 118:667-671.

van de Weg, W.E., S. Giezen, J.L. Maas, and G.J. Galletta. 1993a. Identification of genes for resistance to Phytophthora fragariae in strawberry. Acta Hort. 348:137-138.

van de Weg, W.E., S. Giezen, J.L. Maas, and G.J. Galletta. 1993b. Research on screening methods for resistance to Phytophthora fragariae in strawberry. Acta Hort. 348:513-514.

van der Plank, J.E. 1982. Host-pathogen interaction in plant disease. Academic, New York.

Watkins and J.M. Werts. 1971. Pre-selection for Phytophthora cactorum (Leb. and Cohn) Schroet. resistance in apple seedlings. Ann. Appl. Biol. 67:153156.

Werner, D.J., D.F. Ritchie, D.W. Cain, and E.I. Zehr. 1986. Susceptibility of peaches and nectarines, plant introductions, and other Prunus species to bacterial spot. HortScience 21:127-130.

Williams, E.B. and J. Kuc. 1969. Resistance in Malus to Venturia inaequalis. Annu. Rev. Phytopathol. 7:233-246.

Woeste, K., D. Shaw, and G. McGranahan. 1994. A comparison of genomic and morphological evaluation for selection in interspecific backcross populations of walnut. HortScience 29:462. (Abstr.)

Woeste, K.E., G.H. McGranahan, and M.N. Schroth. 1992. Variation among Persian walnuts in response to inoculation with Xanthomonas campestris pv. juglandis. J. Amer. Soc. Hort. Sci. 117:527-531.

Ye, X., S.K. Brown, R. Scorza, J.C. Cordts, and J. Sanford. 1994. Genetic transformation of peach tissues by particle bombardment. J. Amer. Soc. Hort. Sci. 119:367-373.

Yu, X. 1993. Micropropagation and regeneration of hazelnut (Corylus species). $\mathrm{PhD}$ Diss., Oregon State Univ., Corvallis. 